Основна небезпека пожежі в резервуарному парку з нафтопродуктами полягає в ї каскадному розповсюдженні на сусідні резервуари. Відбувається ие внаслідок прогріву металевих конструкцій резервуара до температури самоспалахування парів нафтопродукту. Тому охолодження резервуарів є перчочерговою задачею при локалізаціі таких пожеж. Одним із найбільш надійних методів охолодження є подача води на стінки резервуара за допомогою гідромоніторів, стаціонарно розташованих поза межами обвалування. При цьому проблему становить розрахунок охолоджувальної дї̈ води $i$ визначення таких параметрів ї̈ подачі, які б забезпечували охолодження конструкиій резервуара до безпечної температури.

Побудовано модель руху струменя води після виходу з насадка пожежного ствола. Запропоновано алгоритм подачі води за допомогою гідромонітора, який забезпечує послідовне чергування переміщення водного струменя по стінці резервуара в горизонтальному $і$ вертикальному напрямках.

Побудовано модель охолоджувальної дї̈ водної плівки, яка утворюеться після удару водного струменя об стінку резервуара. Модель базується на рівняннях теплового балансу для стінки резервуара $i$ водної плівки, а також враховує періодичний рух водного струменя по стінці резервуара. При побудові рівнянь теплового балансу враховано конвекційний $i$ променевий теплообмін з пожежею $і$ навколишнім середовищем. Показано, що розподіл температур по стіниі резервуара $і$ водній плівці описується системою двох нелінійних диференціальних рівнянь першого порядку.

Отримані в роботі результати дозволяють визначити параметри подачі води, які забезпечують охолодження резервуара до безпечної температури

Ключові слова: пожежа в обвалуванні, розподіл температур, конвекційний теплообмін, променевий теплообмін, водний струмінь, водна плівка

$$
\text { (1) }
$$

UDC 614.8

DOI: $10.15587 / 1729-4061.2019 .154669$

\section{DEVELOPING A MODEL OF TANK COOLING BY WATER JETS FROM HYDRAULIC MONITORS UNDER CONDITIONS OF FIRE}

\author{
Y. Abramov \\ Doctor of Technical Sciences, Professor, Chief Researcher \\ Research Center* \\ E-mail: abramov121146@gmail.com \\ O. B a s m a nov \\ Doctor of Technical Sciences, Professor, Chief Researcher \\ Scientific Department on Problems of Civil Defense, \\ Technogenic and Ecological Safety of the Research Center* \\ E-mail: aleksey.basmanov@nuczu.edu.ua \\ J. S a l a mov \\ Adjunct
}

Scientific Department on Problems of Civil Defense, Technogenic and Ecological Safety of the Research Center* E-mail: javid16c@g.mail.com

A. M i k h a y l u k

PhD, Senior Researcher, Head of Doctoral Studies, Adjuncture* E-mail: mihayluk.nuczu@gmail.com

O. Yash chenk o

$\mathrm{PhD}$, Associate Professor Department of Management and Organization of Civil Protection*

E-mail: malahay1984@gmail.com *National University of Civil Defence of Ukraine Chernyshevska str., 94, Kharkiv, Ukraine, 61023

\section{Introduction}

The main hazard of a fire in a tank farm of petroleum products is related to heating the tank under the thermal influence of a fire. Achievement of the temperature of self-ignition of the stored petroleum products by separate elements can lead to flaming combustion of vapors on the breathing fittings of a tank or to an explosion in the gas space of a tank [1]. That is why tanks cooling is a priority task in the localization of fires in a tank farm. The main method of cooling is supplying water onto the walls of a tank by means of irrigation rings located at the upper part of the tanks, hydraulic monitors, or mobile equipment from outside the banking boundaries.

The main disadvantage of using irrigation rings is their damage as a result of an explosion that may precede a fire. In this case, the only means of water supplying to cool a tank is from permanently located hydraulic monitors or mobile equipment of operational rescue units. It should be noted that the time of arrival and deployment of operational rescue units is about 15 minutes, while hydraulic monitors can be employed remotely immediately after the start of a fire.

One of the problems in this case is the calculation of the cooling action of water and determining such parameters of its supply, which would ensure cooling the tank structures to a safe temperature. Therefore, construction of a model of tank cooling by water jets from hydraulic monitors under conditions of a fire is relevant.

\section{Literature review and problem statement}

Analysis of fires in tank farms with petroleum products [2] reveals that a series of severe fires involving more than one tank developed as a result of insufficient effective localization of a primary fire in one tank. In this case, the basic 
method of localization of a fire is cooling a burning tank and neighboring tanks [3].

Paper [4] deals with the study of water jets motion in the air after leaving a fire barrel, but the issue of the cooling action of water jets is not addressed.

Radiation is the main type of heat transfer from a fire of combustible fluid in the open space to the surrounding sites. That is why most attention is given to this kind of heat transfer. Paper [5] focuses on the experimental study of the influence of the spill diameter and the type of burning liquid on the magnitude of thermal radiation from the flame, allowing constructing the model of thermal influence of a fire on neighboring structures, but the problem of their protection from a fire is not explored. In paper [6], the absorption of thermal radiation by vapors of a combustible liquid and smoke particles are additionally taken into consideration, but the problem of fire localization was not solved. The feature of a fire in banking is a possibility of a convective way of transferring the heat from a fire in the case of a close location of a spill to a tank. Paper [7] is devoted to a safe distance of combustible fluid from a fire. In paper [8], a safe distance between the tanks, which make cascade spreading of a fire impossible, was determined, but this distance is longer than the one used in practice. The obtained results indicate that in tank farms, a fire in one tank is a threat to other tanks, therefore, the latter need cooling.

In study [9], the authors constructed a model of thermal influence on a tank of a fire related to the combustible liquid spill in its banking, which also implies the need for cooling a tank. In paper [10], the model of cooling a tank with a water film flowing down its wall was constructed, provided that the transfer of heat from a fire is going exclusively through radiation. At the same time, the contribution of a convection component to the heat flow to a tank for fires in the banking can reach $20 \%$ [9]. All this allows us to assert that it is appropriate to carry out research dedicated to the problem of tank cooling under fire conditions.

\section{The aim and objectives of the study}

The aim of the research is to construct a model for cooling the wall of a vertical steel tank by feeding water jets from a permanently mounted carriage barrels under conditions of a fire in the banking.

To accomplish the aim, the following tasks have been set:

- to develop an algorithm of the water jet motion in the horizontal and vertical planes, which provides cooling of the entire wall of the tank;

- to assess the cooling action of the water film formed by feeding a compact water jet and running down the tank wall;

- to find the temperature distribution on the tank wall and the water film.

\section{The trajectory of water jet motion after it exits a hydraulic monitor}

The basic equation of dynamics of a cooling fluid jet reduced to the unit mass of the extinguishing substance, taking into consideration the fact that the power of resistance of the air environment is proportional to the velocity of the fire-extinguishing substance, can be represented in projections onto the axes of Cartesian coordinate system $\mathrm{XOY}$ in the form [4]

$$
\begin{aligned}
& \frac{d^{2} x}{d t^{2}}+\alpha \frac{d x}{d t}=0 \\
& \frac{d^{2} y}{d t^{2}}+\alpha \frac{d y}{d t}=-g
\end{aligned}
$$

at initial conditions

$$
\begin{aligned}
& x(0)=y(0)=0 \\
& \left.\frac{d x}{d t}\right|_{t=0}=w_{1}=w_{0} \cos \beta ;\left.\frac{d y}{d t}\right|_{t=0}=w_{2}=w_{0} \sin \beta,
\end{aligned}
$$

where $w_{0}$ is the velocity of the cooling fluid on the cross-section of the fire monitor; $\beta$ is the angle of jet feeding; $g$ is the gravity acceleration; $\alpha$ is the resistance coefficient, determined from the expression

$$
\alpha=\frac{0,34}{\rho D}
$$

where $\rho$ is the density of the cooling fluid; $D$ is the diameter of a fire.

Decreasing the order of equations (1) and dividing the variables after the integration, we obtain

$$
\begin{aligned}
& x=\frac{w_{0} \cos \beta}{\alpha}[1-\exp (-\alpha t)] ; \\
& y=\frac{1}{\alpha}\left(w_{0} \sin \beta+\frac{g}{\alpha}\right)[1-\exp (-\alpha t)]-\frac{g t}{\alpha} .
\end{aligned}
$$

After exclusion of time $t$ from the solution (4), (5), we obtain the equation of the trajectory of the cooling fluid jet

$$
y=\frac{g+\alpha w_{0} \sin \beta}{\alpha w_{0} \cos \beta} x+\frac{g}{\alpha^{2}} \ln \left(1-\frac{\alpha x}{w_{0} \cos \beta}\right) .
$$

We will subsequently consider that the fire monitor is mounted at height $h$.

Fig. 1, 2 shows the dependences that determine the range of feeding a cooling fluid jet onto the vertical surface of the tank, obtained with the use of expression (6), if $h=3 \mathrm{~m}$.

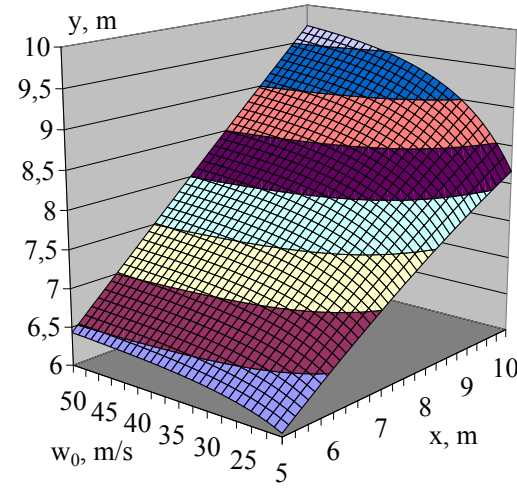

Fig. 1. Dependence of the vertical coordinate of the point of jet hitting the wall of the tank on initial jet velocity and the distance to the tank at the angle of feeding $\beta=35^{\circ}$ 
Fig. 1 meets the condition of mounting a fire monitor at the angle $\beta=35^{\circ}$, and Fig. $2-\beta=55^{\circ}$. Analysis of these dependences indicate that in the second case at a change in velocity of feeding the cooling fluid in the range of $(20 \div 50) \mathrm{m} / \mathrm{s}$, the supply of the cooling fluid is ensured at the level from $13.5 \mathrm{~m}$ to $16.7 \mathrm{~m}$ at the distance from a fire monitor to a tank of $10 \mathrm{~m}$. This fact opens the possibility to control the cooling fluid jet in the vertical plane without changing the angle of its feeding.

It should be noted that in expression (6), the magnitude of resistance coefficient $\alpha$ varied in the range of $(0.02-0.04) \mathrm{s}^{-1}$.

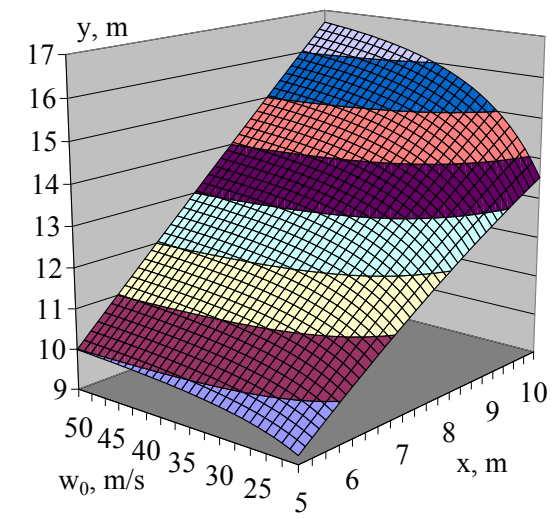

Fig. 2. Dependence of the vertical coordinate of the point of jet hitting the tank wall on the initial jet velocity and the distance to the tank at the angle of feeding $\beta=55^{\circ}$

If we ensure the azimuth motion of a jet, along with its vertical motion, it will become possible to cool a certain area on the vertical surface of the steel tank.

\section{Distribution of temperatures on a tank wall at its cooling with water jets}

\section{1. Interaction of a water jet with a tank wall}

After a water jet hitting a tank wall, a part of water flows down the wall and cools it, and the other rebounds. This part of water is lost and does not take part in cooling the tank wall. The experimental studies in paper [11] revealed that dependence of coefficient of water use $k_{c f}$ on the horizontal component of jet velocity at the moment of hitting w can be approximated by expression

$$
k_{c f}=-0,0114 w+0,4433
$$

for the range of values of velocity $\mathrm{w}=(10 \div 20) \mathrm{m} / \mathrm{s}$. Analysis of expression (7) shows that in the specified range of velocity, the coefficient of water use takes the value of $0.21 \div 0.33$, in this case the coefficient of use decreases at an increase in the jet velocity. Jet velocity at the moment of hitting a tank wall can be found by the differentiation of expression (4):

$$
w=\frac{d x}{d t}=w_{0} \cos \beta \exp (-\alpha t) .
$$

Expressing time $t$ through coordinate $x$ in (4) and substituting it in (8), we obtain

$$
w(x)=w_{0} \cos \beta-\alpha x .
$$

Paper [11] provides the model that describes the width of the water band, formed after jet hitting the tank wall. This width depends on the nozzle diameter, water head at the outlet from the barrel and the height, at which a jet collides with the wall. The specified dependence is shown in paper [11] in the form of the tables for the nozzles with the diameter of $13 \mathrm{~mm}, 19 \mathrm{~mm}, 25 \mathrm{~mm}$; the height of $12 \mathrm{~m}, 15 \mathrm{~m}, 18 \mathrm{~m}$; the head of $20 \mathrm{~m}, 40 \mathrm{~m}$, and $60 \mathrm{~m}$. Their analysis shows that the width of the band does not actually depend on the height and in this range of values can be represented only as the dependence on the nozzle diameter and the head (Table 1). In this case, the relative error of this approximation does not exceed $4.4 \%$.

Table 1

Width of water band $(\mathrm{m})$, which runs down the tank wall

\begin{tabular}{|c|c|c|c|c|}
\hline \multirow{2}{*}{$\begin{array}{c}\text { Type of } \\
\text { barrel }\end{array}$} & \multirow{2}{*}{$\begin{array}{c}\text { Nozzle diam- } \\
\text { eter, } \mathrm{mm}\end{array}$} & \multicolumn{3}{|c|}{ Head at the outlet of the barrel, $\mathrm{m}$} \\
\cline { 3 - 5 } & 25 & 20 & 40 & 60 \\
\hline Carriage & 25 & 2.86 & 2.46 \\
\hline A & 19 & 2.30 & 2.32 & 2.10 \\
\hline B & 13 & 1.72 & 1.64 & 1.42 \\
\hline
\end{tabular}

Taking into consideration the rebound of the part of water after hitting the tank wall, the intensity of water flowing down the tank wall can be estimated by expression [11]

$$
I=(-0,0114 w+0,4433) G,
$$

where $G$ is the water consumption by the water barrel.

Taking the angle of mounting a fire hydraulic monitor $\beta=55^{\circ}$ and taking into consideration (10), we will obtain the intensity of water flowing down the tank wall depending on the barrel diameter and the head - Table 2 .

Analysis of the data, presented in Table 2, reveals that intensity of water flowing down the tank wall makes up $(0.49 \div 1.50) \mathrm{l} /(\mathrm{m} \cdot \mathrm{s})$.

Table 2

Intensity of water flowing down the tank wall, I/(m.s)

\begin{tabular}{|c|c|c|c|c|}
\hline \multirow{2}{*}{$\begin{array}{c}\text { Type of } \\
\text { barrel }\end{array}$} & \multirow{2}{*}{$\begin{array}{c}\text { Nozzle diam- } \\
\text { eter, mm }\end{array}$} & \multicolumn{3}{|c|}{ Head at the outlet of the barrel, $\mathrm{m}$} \\
\cline { 3 - 5 } & 25 & 20 & 40 & 60 \\
\hline Carriage & 25 & 1.25 & 1.50 \\
\hline A & 19 & 0.75 & 0.87 & 1.01 \\
\hline B & 13 & 0.49 & 0.59 & 0.70 \\
\hline
\end{tabular}

When constructing the model of the cooling action of water jets, we will accept the following assumptions.

1. After a water jet hitting the tank wall, the water flows down the wall under the gravity influence, forming the vertical band, the width of which $\ell$ depends on the nozzle diameter and the head at the outlet from the barrel (Table 1).

2. A water jet moves in a cyclic way on the tank wall in the horizontal (due to switching valves) and vertical (due to changes in pressure) direction, passing the entire area of its responsibility and returns to the starting point by the same territory, but in the opposite direction (Fig. 3). Thus, the contact area of a jet with the wall has the height of $\mathrm{H}-\mathrm{h}$ and the width $L=n \cdot \ell$, where $n$ is a natural number.

3. Motion of a jet vertically from the top to the bottom point takes time $t_{v}$ and goes on at constant speed.

4. Motion of a jet in the horizontal direction occurs instantly, but at the upper point, a jet stays for time $t_{u}$, both before and after the motion (Fig. 4). 
5. The water film is completely transparent for heat exchange by radiation of the tank wall with a flame tongue and the environment.

Analysis of Fig. 4 shows that a jet stays at each band within time $t_{v}+t_{u}$. But an arbitrary point located at height $z$ on the band cooled by a jet will not always be covered with water. The time, during which the point is cooled by the water film, is described by expression:

$$
t_{c}= \begin{cases}t_{u}+t_{v}, & z \leq h, \\ t_{u}+\frac{t_{v}}{H-h}(H-z) & , h \leq z \leq H .\end{cases}
$$

Because the cooling area is split into $\mathrm{n}$ vertical bands that do not intersect, the time portion, when a water film will cover the point, located on the tank wall at height $z$, is

$$
A_{c}(z)= \begin{cases}1 / n, & z \leq h, \\ \frac{1}{n} \frac{t_{u}+\frac{t_{v}}{H-h}(H-z)}{t_{u}+t_{v}}, & h \leq z \leq H .\end{cases}
$$

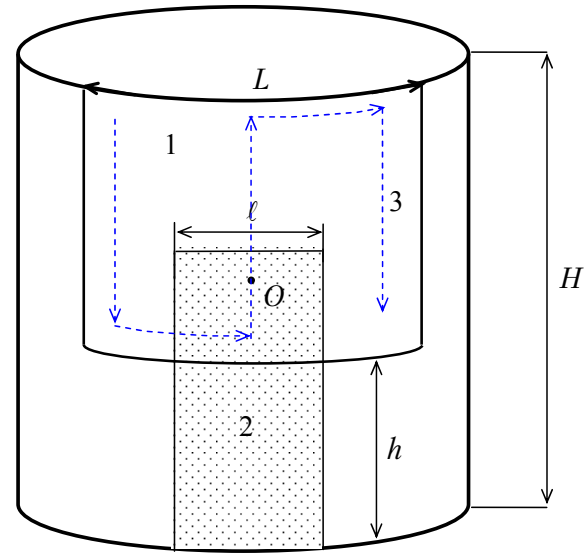

Fig. 3. The circuit of tank cooling by a water jet: $1-$ area of responsibility on the tank wall, on which a water jet moves; 2 - water film that flows down the tank wall after jet getting at point $O ; 3-$ trajectory of water jet motion on the tank wall

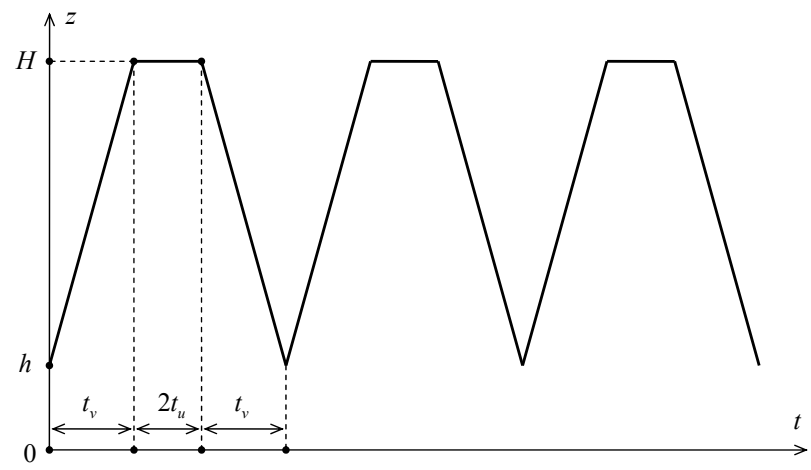

Fig. 4. Time-dependent change in the vertical coordinate of the point of contact of a jet with the tank wall

Consider the elemental area on the tank wall. In the absence of cooling, its temperature is described by the differential equation [9]

$$
\begin{aligned}
& \frac{d T_{w}}{d t}=\frac{c_{0} \varepsilon_{s} \varepsilon_{w}}{\rho_{w} \delta_{w} c_{w}}\left[\left(\frac{T_{s}}{100}\right)^{4}-\left(\frac{T_{w}}{100}\right)^{4}\right] \psi+ \\
& +\frac{c_{0} \varepsilon_{w}}{\rho_{w} \delta_{w} c_{w}}\left[\left(\frac{T_{0}}{100}\right)^{4}-\left(\frac{T_{w}}{100}\right)^{4}\right](1-\psi)+ \\
& +\frac{\alpha_{2}\left(T_{f}-T_{w}\right)}{\rho_{w} \delta_{w} c_{w}}+\frac{c_{0} \varepsilon_{w}^{2}}{\rho_{w} \delta_{w} c_{w}}\left[\left(\frac{T_{0}}{100}\right)^{4}-\left(\frac{T_{w}}{100}\right)^{4}\right]+\frac{\alpha_{5}\left(T_{0}-T_{w}\right)}{\rho_{w} \delta_{w} c_{w}},
\end{aligned}
$$

where $c_{0}=5.67 \mathrm{Wt} /\left(\mathrm{m}^{2} \cdot \mathrm{K}^{4}\right)$ is the constant; $T_{w}$ is the temperature of the elemental area; $T_{s}$ is the temperature of radiating surface of the flame tongue; $T_{0}$ is the temperature of the environment; $\varepsilon_{s}, \varepsilon_{w}$ are the degrees of blackness of flame tongue surface and the tank wall, respectively; $\rho_{w}, \mathrm{c}_{w}, \delta_{w}$ are the density, specific heat capacity and wall thickness, respectively; $\alpha_{2}$ is the coefficient of convective heat exchange between the tank wall and the air; $\alpha_{5}$ is the coefficient of convective heat exchange between the tank wall and the vapor and air mixture in the gas space of the tank. As the initial condition for equation (11), we will accept

$$
T_{w}(0)=T_{0} .
$$

In the case of tank cooling by water jets, it is necessary to replace the term

$$
\theta_{f}=\frac{\alpha_{2}\left(T_{f}-T_{w}\right)}{\rho_{w} \delta_{w} c_{w}},
$$

that corresponds to convection heat exchange with air masses, with

$$
\theta_{c f}=\frac{\alpha_{c f}\left(T_{c f}-T_{w}\right)}{\rho_{w} \delta_{w} c_{w}},
$$

which describes convective heat exchange with the water film that flows down the tank wall, where $\alpha_{c f}$ is the coefficient of convection heat exchange with the water film; $T_{c f}$ is the water film temperature at the point of contact with elemental area.

Paper [12] presents the estimates of the parameters of the water film that flows down the tank wall:

- film thickness:

$$
\delta=0,055 I^{0,6}
$$

where $I$ is the intensity of water flowing, $\mathrm{m}^{3} /(\mathrm{m} \cdot \mathrm{s})$;

- velocity of motion of the water film

$$
w_{c f}=18,2 I^{0,4} \text {; }
$$

- coefficient of convective heat exchange with the tank wall

$$
\alpha_{c f}=\left(238,53 T_{c f}-45098\right) I^{0,25} .
$$

We will note that at the intensity of flowing down of $(0.49 \div 1.50) \mathrm{l} /(\mathrm{m} \cdot \mathrm{s})$, the film thickness, velocity of flowing down and coefficient of convection heat exchange will make up: $\delta=(0.6 \div 1.1) \mathrm{mm}, w_{c f}=(0.9 \div 1.4) \mathrm{m} / \mathrm{s}, \alpha_{c f}=$ $=(4.7 \div 6.3) \mathrm{kW} /\left(\mathrm{m}^{2} \cdot \mathrm{K}\right)\left(\right.$ at water temperature $\left.T_{c f}=50{ }^{\circ} \mathrm{C}\right)$.

Combining (12) and (15), we obtain 


$$
\theta_{c f}=\frac{\left(238,53 T_{c f}-45098\right)\left(T_{c f}-T_{w}\right)}{\rho_{w w} \delta_{w} c_{w w}} I^{0,25} .
$$

Flowing down, the water film will be heated by taking the heat from the tank wall. This means that as a result of motion of a water jet vertically on the tank wall, in term $\theta_{c f}$, the value of temperature of the water film $T_{c f}$ will change, i. e., $\theta_{c f}$ is the function of the vertical coordinate of the point of water hitting the wall: $\theta_{c f}=\theta_{c f}(y)$. To simplify, we will consider the averaged value of $\Theta_{c f}$.

For the point located at height $z$, the value of y will be found in the range of $z \ldots H$, and the averaged on this range value of $\Theta_{c f}$ :

$$
\begin{aligned}
& \Theta_{c f}=\frac{1}{H-z} \int_{z}^{H} \theta_{c f}(y) \mathrm{d} y= \\
& =\frac{1}{H-z} \frac{I^{0,25}}{\rho_{w} \delta_{w} c_{w}} \int_{z}^{H}\left(238,53 T_{c f}(y)-45098\right)\left(T_{c f}(y)-T_{w}\right) \mathrm{d} y .
\end{aligned}
$$

Given the proportion of time, when that the point at height $z$ is covered with a water film, we write down

$$
\theta(z)=A_{c}(z) \Theta_{c f}+\left(1-A_{c}(z)\right) \theta_{f} .
$$

Then the differential equation (11), which describes the temperature of the elemental area on the tank wall, will be converted into

$$
\begin{aligned}
& \frac{d T_{w}}{d t}=\frac{c_{0} \varepsilon_{s} \varepsilon_{w}}{\rho_{w} \delta_{w} c_{w}}\left[\left(\frac{T_{s}}{100}\right)^{4}-\left(\frac{T_{w}}{100}\right)^{4}\right] \psi+ \\
& +\frac{c_{0} \varepsilon_{w}}{\rho_{w} \delta_{w} c_{w}}\left[\left(\frac{T_{0}}{100}\right)^{4}-\left(\frac{T_{w}}{100}\right)^{4}\right](1-\psi)+ \\
& +\theta(z)+\frac{c_{0} \varepsilon_{w}^{2}}{\rho_{w} \delta_{w} c_{w}}\left[\left(\frac{T_{0}}{100}\right)^{4}-\left(\frac{T_{w}}{100}\right)^{4}\right]+\frac{\alpha_{5}\left(T_{0}-T_{w}\right)}{\rho_{w} \delta_{w} c_{w}} .
\end{aligned}
$$

Differential equation (16) describes heating the tank wall under conditions of its cooling by the water jet according to the algorithm presented in Fig. 3, 4.

We will note that, unlike previous papers, the approach that is based on the equation of thermal balance of elemental area on the tank wall, is used not only for boundary cases when the wall is in contact only with a water film [12] or only with the surrounding air [9], but also is extended to the case when the wall alternately interacts with these two environments.

\section{wall}

5. 2. Heating the water film flowing down the tank

Consider the motion of elemental water volume $\Delta \mathrm{V}=\Delta S \delta$ on the wall, the location of which is described by the vertical coordinate $\mathrm{z}(t) ; \Delta S$ is the are of the surface that is in contact with the tank wall. Motion velocity $\omega_{c}$ is constant and is determined from formula (14).

At the initial moment of time $t=0$, elemental volume begins to move from the point of jet hitting the tank wall:

$$
\begin{aligned}
& z(0)=y, \\
& T_{c f}(0)=T_{0},
\end{aligned}
$$

Within time $d t$, the elemental volume of water passes the distance

$$
d z=-w_{c} d t
$$

and receives heat from the wall

$$
d Q_{w}=\alpha_{c f}\left(T_{w}(z, t)-T_{c f}\right) \Delta S d t
$$

and from air masses

$$
d Q_{f}=\alpha_{f}\left(T_{f}(z)-T_{c f}\right) \Delta S d t
$$

where $T_{f}(z)$ is the temperature of the air masses, the water film constants with; $\alpha_{f}$ is the coefficient of convectional heat exchange between the water film and the air.

Due to the small thickness of the film and developed turbulence, resulting heat is evenly distributed throughout its entire thickness, increasing the temperature of the elemental volume by magnitude $d T_{c f}$

$$
d Q_{w}+d Q_{f}=\delta \Delta S \rho_{c} c_{c} d T_{c f},
$$

where $\mathrm{c}_{c}, \rho_{c}$ are the heat capacity and water density, respectively. Combining expressions (18) (20), we obtain

$$
\delta \rho_{c} c_{c} d T_{c f}=\left[\alpha_{c f}\left(T_{w}(z, t)-T_{c f}\right)+\alpha_{f}\left(T_{f}(z)-T_{c f}\right)\right] d t .
$$
obtain

Combining (17) and (21) and considering $I=\delta w_{c}$, we

$$
\frac{d T_{c f}}{d z}=-\frac{1}{\rho_{c} c_{c} I}\left[\alpha_{c f}\left(T_{w}(z, t)-T_{c f}\right)+\alpha_{f}\left(T_{f}(z)-T_{c f}\right)\right] .
$$

To determine a sufficient level of cooling, the boundary distribution of temperatures is essential; it is established by the tank wall and in the water film, on the wall of the tank and the water film, i. e. $d T_{w} / d t=0$. Then the differential equation (16) will be converted into the algebraic equation

$$
\begin{aligned}
& \frac{c_{0} \varepsilon_{s} \varepsilon_{w}}{\rho_{w} \delta_{w} c_{w}}\left[\left(\frac{T_{s}}{100}\right)^{4}-\left(\frac{T_{w}(z)}{100}\right)^{4}\right] \psi+ \\
& +\frac{c_{0} \varepsilon_{w}}{\rho_{w} \delta_{w} c_{w}}\left[\left(\frac{T_{0}}{100}\right)^{4}-\left(\frac{T_{w}(z)}{100}\right)^{4}\right](1-\psi)+ \\
& +\theta(z)+\frac{c_{0} \varepsilon_{w}^{2}}{\rho_{w} \delta_{w} c_{w}}\left[\left(\frac{T_{0}}{100}\right)^{4}-\left(\frac{T_{w}(z)}{100}\right)^{4}\right]+ \\
& +\frac{\alpha_{5}\left(T_{0}-T_{w}(z)\right)}{\rho_{w} \delta_{w} c_{w}}=0,
\end{aligned}
$$

and equation (22) will take the form

$$
\frac{d T_{c f}}{d z}=-\frac{1}{\rho_{c} c_{c} I}\left[\alpha_{c f}\left(T_{w}(z)-T_{c f}\right)+\alpha_{f}\left(T_{f}(z)-T_{c f}\right)\right] .
$$

Combined solution of (23) and (24) allows estimating the temperature of the tank wall under conditions of its cooling by water jets. It is sufficient to cool the tank wall below the temperature of ignition of the oil product, that is, to the temperature of $(150 \div 250){ }^{\circ} \mathrm{C}$, depending on the type of oil products. 


\section{Discussion of results of studying the model of tank cooling with water jets}

The dependence of the vertical coordinate of a water jet on its velocity at the outlet of the nozzle of a fire barrel allows replacing the angular motion of a barrel in the vertical plane by varying the water jet velocity, which in turn is achieved by changing the head in a barrel. It should be noted that vertical steel tanks are additionally protected by the earth banking, which prevents the spill of combustible fluid as a result of the accident. Taking into consideration the banking thickness of $(2 \div 3 \mathrm{~m})$ and the distance from the banking to the tank $(6 \mathrm{~m})$, the typical distance from a hydraulic monitor to the tank wall will make up about $10 \mathrm{~m}$. Under such conditions, varying the jet velocity in the range of $(20 \div 50) \mathrm{m} / \mathrm{s}$ at the outlet of the nozzle of a fire barrel ensures cooling the tank wall at the height of $(13.5 \div 16.7) \mathrm{m}$. The lower part of the tank wall will be cooled due to the water film, which is formed after the jet hitting the wall.

Linear approximation of the dependence of coefficient of water use on the horizontal jet velocity at the moment of hitting the wall (10) and degree dependences of water film thickness (13) and velocity of its flowing down the wall (14) enable obtaining an assessment of coefficient of convective heat transfer from the wall to the water film. This opens up possibilities for constructing a model of the cooling action of the water film on the tank wall, which takes into consideration convection and radiation components of heat flows.

The constructed model relies on the assumption that in the process of cooling, the water flowing down the tank wall is not heated to boiling temperature. Therefore, the practical use of the model of cooling the tank wall with a water jet requires checking that the temperature of the water film, obtained from (23), (24), do not exceed the temperature of water boiling. In the opposite case, in the lower part of the tank, water can start boiling, which will repel the water film from the tank wall. As a result, cooling efficiency will be significantly lower.

The length of the perimeter of the tank having capacity of $10,000 \mathrm{~m}^{3}$ is $90 \mathrm{~m}$. Tank cooling around the entire perimeter should involve at least three fire barrels, which gives the width of the area of responsibility for one barrel of about $30 \mathrm{~m}$. At the same time, water supply by a hydraulic monitor channels provides cooling the area of the width of only $(1.4 \div 2.9) \mathrm{m}$ (Table 1$)$, i. e., no more than $10 \%$ of the required. This causes the need to move the jet in the horizontal direction. Such motion can be implemented both by the mechanical rotation of the barrel, and using a system of nozzles, each of which provides cooling a certain part of the tank perimeter and the water between nozzles is switched over with the help of fast-acting valves.

Relatively small tanks (of the volume of up to $1,000 \mathrm{~m}^{3}$ inclusive) can be protected by hydraulic monitors without jet motion in the horizontal direction. Thus, for the tank of the capacity of $1,000 \mathrm{~m}^{3}$ the perimeter length is $11 \mathrm{~m}$, which allows providing its protection with the help of four hydraulic monitors.

The motion of the jet on the wall in vertical direction prevents water film sintering at the lower part of the tank without increasing the intensity of water supply. Alternating vertical and horizontal motion of the water jet leads to its circular motion on the tank wall.

Because a water jet with a certain period goes around its area of responsibility on the tank wall, the wall temperature will fluctuate in the vicinity of the boundary distribution. The longer the time for jet full going around its area of responsibility, the larger the amplitude of oscillations. Thus, a fire monitor with a higher velocity of jet motion in the horizontal and vertical directions will ensure more efficient cooling of the tank.

\section{Conclusions}

1. The model of the water jet motion from the moment of exiting the fire barrel to the collision with the tank wall, which takes into consideration the effect of air resistance on the jet trajectory, was constructed. It was shown that the variation of water velocity at the outlet of the fire barrel nozzle in the range of $(20 \div 50) \mathrm{m} / \mathrm{s}$ leads to the jet motion on the tank wall along the height in the range of $(13.5 \div 16.7) \mathrm{m}$.

2. We developed the algorithm for relatively large tanks (of capacity of more than $1,000 \mathrm{~m}^{3}$ ), the algorithm of jet motion on the tank wall that lies in sequential alternation of the vertical and horizontal motions, which makes it possible to ensure cooling a certain part of the tank wall. The tanks of the volume of up to $1,000 \mathrm{~m}^{3}$ inclusive can be cooled by hydraulic monitors without jet motions in the horizontal direction.

3. The model of cooling the tank wall with water jets, which takes into consideration the jet motion on the wall and rebound of a part of water after jet hitting the wall, was constructed. The model is based on the equation of thermal balance for a wall and the water film flowing down it and takes into consideration convective and radiation heat exchange. It was shown that at water feeding by the standard fire barrels at an angle of $55^{\circ}$ to the horizon and the head of $(20 \div 60) \mathrm{m}$, a flowing water film of the width of $(1.4 \div 2.9) \mathrm{m}$ is formed on the tank wall, and coefficient of convective heat exchange between the wall and water is $(4.7 \div 6.3) \mathrm{kW} /\left(\mathrm{m}^{2} \cdot \mathrm{K}\right)$.

4. It was shown that the temperature distribution on the tank wall and the water film is described by the system of two nonlinear differential equations of the first order. Their combined solution allows determining whether these parameters of water supply ensure wall cooling to safe temperatures of $(150 \div 250){ }^{\circ} \mathrm{C}$, depending on the type of oil products in the tank. In this case, the estimated temperature of the water film should be controlled additionally, because its sintering leads to film repulsion from the wall and, as a consequence, to decreasing the efficiency of cooling.

1. Quantitative assessment of safety barrier performance in the prevention of domino scenarios triggered by fire / Landucci G., Argenti F., Tugnoli A., Cozzani V. // Reliability Engineering \& System Safety. 2015. Vol. 143. P. 30-43. doi: https://doi.org/10.1016/ j.ress.2015.03.023 
2. Safety of atmospheric storage tanks during accidental explosions / Noret E., Prod'homme G., Yalamas T., Reimeringer M., Hanus J.-L., Duong D.-H. // European Journal of Environmental and Civil Engineering. 2012. Vol. 16, Issue 9. P. 998-1022. doi: https://doi.org/10.1080/19648189.2012.699740

3. The Cooling Water Intensity Design of Crude Oil Tanks Based on Standard Analysis and New Calculation Model / Liu B., Ye F., Wu K., Wang M., Zhu M. // ICPTT 2012. 2012. doi: https://doi.org/10.1061/9780784412619.072

4. Trettel B., Ezekoye O. A. Theoretical range and trajectory of a water jet // Proceedings of ASME 2015 International Mechanical Engineering Congress and Exposition. Houston, 2015. URL: http://trettel.org/pubs/2015/Trettel-2015-Theoretical-range-and-trajectory-of-a-water-jet.pdf

5. Thermal exposure from large scale ethanol fuel pool fires / Sjöström J., Amon F., Appel G., Persson H. // Fire Safety Journal. 2015. Vol. 78. P. 229-237. doi: https://doi.org/10.1016/j.firesaf.2015.09.003

6. Pool fires - An empirical correlation / Ditch B. D., de Ris J. L., Blanchat T. K., Chaos M., Bill R. G., Dorofeev S. B. // Combustion and Flame. 2013. Vol. 160, Issue 12. P. 2964-2974. doi: https://doi.org/10.1016/j.combustflame.2013.06.020

7. Fire safety distances for open pool fires / Sudheer S., Kumar L., Manjunath B. S., Pasi A., Meenakshi G., Prabhu S. V. // Infrared Physics \& Technology. 2013. Vol. 61. P. 265-273. doi: https://doi.org/10.1016/j.infrared.2013.09.006

8. Santos F. da S., Landesmann A. Thermal performance-based analysis of minimum safe distances between fuel storage tanks exposed to fire // Fire Safety Journal. 2014. Vol. 69. P. 57-68. doi: https://doi.org/10.1016/j.firesaf.2014.08.010

9. Model of thermal effect of fire within a dike on the oil tank / Abramov Y. A., Basmanov O. E., Salamov J., Mikhayluk A. A. // Naukovyi Visnyk Natsionalnoho Hirnychoho Universytetu. 2018. Issue 2. P. 95-101. doi: https://doi.org/10.29202/ nvngu/2018-2/12

10. A novel method to design water spray cooling system to protect floating roof atmospheric storage tanks against fires / Alimohammadi I., Nourai F., Daryalaal M. J., Ghasemi A. M. // Iranian Journal of Health, Safety \& Environment. 2015. Vol. 2 , Issue 1. P. 235-242. URL: http://www.ijhse.ir/index.php/IJHSE/article/view/61

11. Basmanov A. E., Mihaylyuk A. A. Lokalizaciya pozharov v rezervuarah s nefteproduktami. Kharkiv: NUCZU, 2011. 108 p. URL: http://repositsc.nuczu.edu.ua/handle/123456789/261

12. Basmanov O. E., Kulik Y. S. Estimation of the convection heat exchange rate for tank shells covered with falling water film // East journal of security studies. 2017. Vol. 1. P. 145-154. URL: http://repositsc.nuczu.edu.ua/handle/123456789/6121 